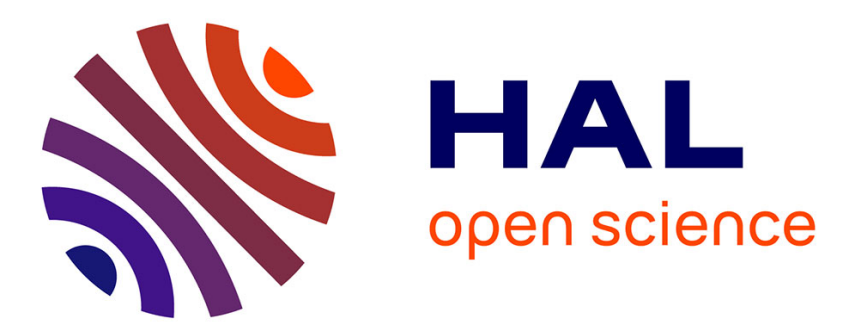

\title{
Influence of lactose on the formation of whey protein microparticles obtained by dry heating at alkaline pH
}

Elise Schong, Marie-Hélène Famelart

\section{To cite this version:}

Elise Schong, Marie-Hélène Famelart. Influence of lactose on the formation of whey protein microparticles obtained by dry heating at alkaline pH. Food Hydrocolloids, 2019, 87, pp.477-486. 10.1016/j.foodhyd.2018.08.018 . hal-01867984

\section{HAL Id: hal-01867984 \\ https://hal.science/hal-01867984}

Submitted on 4 Sep 2018

HAL is a multi-disciplinary open access archive for the deposit and dissemination of scientific research documents, whether they are published or not. The documents may come from teaching and research institutions in France or abroad, or from public or private research centers.
L'archive ouverte pluridisciplinaire HAL, est destinée au dépôt et à la diffusion de documents scientifiques de niveau recherche, publiés ou non, émanant des établissements d'enseignement et de recherche français ou étrangers, des laboratoires publics ou privés. 


\title{
Influence of lactose on the formation of whey protein microparticles obtained by dry heating at alkaline $\mathrm{pH}$
}

\author{
Elise Schong, Marie-Hélène Famelart* \\ STLO, UMR 1253, INRA, Agrocampus Ouest, 35000, Rennes Cedex, France
}

\section{A R T I C L E I N F O}

\section{Keywords:}

Whey protein

Microparticle

Dry heating

Aggregation

Maillard reaction

Lactose

\begin{abstract}
A B S T R A C T
Dry heating $(\mathrm{DH})$ at $100{ }^{\circ} \mathrm{C}$ of a whey protein isolate powder conditioned at $\mathrm{pH} 9.5$ leads to the formation of stable, large and porous whey protein microparticles (WPM), resulting from crosslinking of proteins in the powder. The Maillard reaction (MR) is probably involved in the formation of these WPM. To confirm the role played by the MR and understand the protein changes occurring during particle formation, we analyzed the properties of the powders (such as their water activity $\left(\mathrm{a}_{\mathrm{w}}\right)$ and color) and characterized the WPM formed after 3 and $36 \mathrm{~h}$ of DH in powders with increasing amounts of added lactose. Adding lactose and prolonging the time of $\mathrm{DH}$ increased the extent of protein denaturation and the rate of formation of WPM and the yield of conversion of powder into WPM, but led to decreases in their water content. Addition of lactose also altered the kinetics of the MR, the increase in $a_{w}$ and the formation of WPM. The MR, as followed by powder browning, was complete within $3 \mathrm{~h}$ of DH irrespective of the amount of added lactose. In contrast, the increase in $\mathrm{a}_{\mathrm{w}}$, thought to be due to progress of the MR, continued to increase from 3 to $36 \mathrm{~h}$ of DH. Formation of WPM went on increasing from 3 to $36 \mathrm{~h}$ of $\mathrm{DH}$ at low to medium levels of lactose, but was complete by $3 \mathrm{~h}$ of DH at high levels of lactose. In conclusion, the formation of WPM was not simply related to the MR and needs further investigation.
\end{abstract}

\section{Introduction}

Whey protein isolate (WPI) powders are commonly used in the food industry because of their nutritional value and functional properties. Most studies on WPI aggregation and denaturation have involved heating of WPIs in a liquid form to investigate enhancing their functional properties (Nicolai, Britten, \& Schmitt, 2011). However, an increasing number of studies have investigated heating in a dry state, i.e. heating of the protein powder (Gulzar, Bouhallab, Jeantet, Schuck, \& Croguennec, 2011; Hiller \& Lorenzen, 2010; Ibrahim, Kobayashi, \& Kato, 1993; Liu \& Zhong, 2013; Liu, Kong, Han, Sun, \& Li, 2014; Mulcahy, Park, Drake, Mulvihill, \& O'Mahony, 2018; Schmitt, Bovay, \& Frossard, 2005; Wang, He, Labuza, \& Ismail, 2013).

Previous studies have shown that dry heating (DH) at $100{ }^{\circ} \mathrm{C}$ for up to $72 \mathrm{~h}$ of a freeze-dried powder conditioned at $\mathrm{pH} 9.5$ with a water activity $\left(\mathrm{a}_{\mathrm{w}}\right)$ of around 0.2 leads to the formation of whey protein microparticles (WPM) (Famelart, Schong, \& Croguennec, 2018). These WPM obtained by DH of freeze-dried powders have the same angular shape as the powder flakes and are highly heterogeneous in size, ranging from 50 to $2000 \mu \mathrm{m}$ (Famelart et al., 2018). In contrast, WPM obtained from DH of spray-dried powders are spherical with an open hollow structure and a narrower size range centered around 60-90 $\mu \mathrm{m}$
(Schong \& Famelart, 2018). Due to their large size, WPM obtained by these $\mathrm{DH}$ process sediment in a few minutes at $20^{\circ} \mathrm{C}$ when the suspensions are stored in quiescent conditions.

DH leads to the browning of powders and the formation of advanced glycation end-products (AGEs) via the Maillard reaction (MR). The MR is a nonenzymatic browning reaction initiated by the interaction of a free amino group of a protein or an amino acid with a carbonyl group of a reducing sugar. It then involves a complex cascade of reactions including rearrangements, isomerizations, dehydrations, cyclizations, enolizations, retro-aldolizations, caramelizations, condensations, cleavages and polymerizations (Ames, 1992; Hiller \& Lorenzen, 2010; Martins, Jongen, \& van Boekel, 2000). These reactions lead to the formation of heterogeneous MR products, including melanoidins, which are the brown nitrogenous polymers responsible for browning (Ames, 1992). Furthermore, several studies have reported that glycosylation of food proteins through the MR can improve the functional properties of these proteins, such as their gelling or foaming properties (Handa \& Kuroda, 1999; Hiller \& Lorenzen, 2010; Martinez-Alvarenga et al., 2014; Mulcahy et al., 2018; Schong \& Famelart, 2017).

The aim of this study was to investigate the effect of addition of lactose to a commercial whey protein powder on the formation of WPM induced by $\mathrm{DH}$ and to increase our knowledge on the mechanisms of

\footnotetext{
* Corresponding author.

E-mail address: marie-helene.famelart@inra.fr (M.-H. Famelart).
} 
formation of these WPM.

\section{Materials and methods}

\subsection{Materials}

A commercial whey protein (WP) powder was obtained from a confidential source. The protein content of the WP powder was $911 \mathrm{~g} \cdot \mathrm{kg}^{-1}$, as determined by the Kjeldahl method using 6.38 as the conversion factor. Approximately $82 \%$ of this protein was WP and around $18 \%$ was casein, as a mix of $\alpha s 1, \alpha s 2, \beta$ and $\kappa$ caseins, as determined by polyacrylamide gel electrophoresis (Supplementary Fig. S1).

Both carboxymethyllysine (CML) and (D2)-CML were provided by PolyPeptide Laboratories France SAS (Strasbourg, France). Lithium buffers at $\mathrm{pH} 2.20, \mathrm{pH} 2.80, \mathrm{pH} 3.00, \mathrm{pH} 3.15, \mathrm{pH} 3.50$ and $\mathrm{pH} 3.55$ and ninhydrin reagent (EZ Nin reagent) were obtained from Biochrom Ltd (Cambridge, UK). Potassium acetate, $\alpha$-Lactose monohydrate (4-O- $\beta$-Dgalactopyranosyl- $\alpha$-D-glucose), amino acid standards, nonafluoropentanoic acid (NFPA) 97\%, hydrochloric acid (HCl) 37\%, trifluoroacetic acid (TFA), sodium hydroxide, sodium borohydride and boric acid were obtained from Sigma-Aldrich (Saint Quentin Fallavier, France). Acetonitrile, glacial acetic acid, and sodium acetate trihydrate were obtained from VWR international (Fontenay-sous-Bois, France). $\beta$ lactoglobulin $(\beta-\mathrm{Lg})$ and $\alpha$-lactalbumin $(\alpha$-lac) were obtained from Davisco Foods International Inc. (Le Sueur, MN, USA).

\subsection{Preparation of dry-heated powders}

The powder of $\alpha$-Lactose monohydrate was dispersed in distilled water at $20^{\circ} \mathrm{C}$ and stirred for $15 \mathrm{~min}$ to reach concentrations from 0 to $30 \mathrm{~g} \mathrm{~kg}^{-1}$. The WP powder was then added to reach a final concentration of $150 \mathrm{~g}$ of powder. $\mathrm{kg}^{-1}$ and the preparation was then stirred overnight at $4^{\circ} \mathrm{C}$. The range of lactose concentrations used was far below the maximum solubility of lactose at $20^{\circ} \mathrm{C}$ or $4^{\circ} \mathrm{C}$. The weight ratio of added lactose to protein (L:P) ranged between 0 (no added lactose) and $2.09 \mathrm{~g}$ of lactose $/ 10 \mathrm{~g}$ of protein at the highest level. The ratio $\mathrm{L}: \mathrm{P}=2.09 \mathrm{~g} / 10 \mathrm{~g}$ is approximately equivalent to $11 \mathrm{~mol}$ lactose/ mol protein, assuming that the WP consisted of $82 \% \beta$ - Lg and $18 \% \alpha$ lac, and using molecular weights of 18283 mol.g ${ }^{-1}$ and $14173 \mathrm{~mol} . \mathrm{g}^{-1}$, respectively. The $\mathrm{pH}$ of the solutions was then adjusted to 9.5 with 5 to $1 \mathrm{~mol} . \mathrm{L}^{-1} \mathrm{NaOH}$, and the solutions were then rapidly frozen and freezedried.

In order to obtain fine powder particles, freeze-dried powders were first crushed in a Lab Blender 400 (Stomacher, Humeau, La Chapellesur-Erdre, France) for $1 \mathrm{~min}$ to obtain a rough powder, and then crushed in a coffee grinder (Prepline, SEB, Mayenne, France) for $40 \mathrm{~s}$ to obtain a fine powder. Powders were then stored for 2 weeks at $20^{\circ} \mathrm{C}$ in a desiccator with a saturated $\mathrm{CH}_{3} \mathrm{CO}_{2} \mathrm{~K}$ solution to obtain an $\mathrm{a}_{\mathrm{w}}$ of $0.25 \pm 0.01$. Two weeks were sufficient to reach an equilibrium at the targeted $\mathrm{a}_{\mathrm{w}}$ value, as checked with an $\mathrm{a}_{\mathrm{w}}$ meter (Decagon Aqualab $3 \mathrm{TE}$, Dardilly, France). Powders were then heated at $100^{\circ} \mathrm{C}$ for $3 \mathrm{~h}$ and $36 \mathrm{~h}$ at L:P from 0 up to $2.09 \mathrm{~g} / 10 \mathrm{~g}$ of proteins, and for $1 \mathrm{~h}$ at $\mathrm{L}: \mathrm{P}=2.09 \mathrm{~g} / 10 \mathrm{~g}$ of protein and for $96 \mathrm{~h}$ at $\mathrm{L}: \mathrm{P}=0 \mathrm{~g} / 10 \mathrm{~g}$ in tightly sealed Pyrex tubes. The whole dry-heated powder preparation procedure was carried out twice on two samples of the commercial WP powder.

\subsection{Preparation of suspensions of whey protein microparticles}

The dry-heated powders were reconstituted to a concentration of just below $10 \mathrm{~g}$ of powder. $\mathrm{kg}^{-1}$ in distilled water with $0.2 \mathrm{~g} \mathrm{~kg}^{-1}$ sodium azide. The suspension was stirred overnight at $300 \mathrm{rpm}$ at room temperature. The $\mathrm{pH}$ was then slowly adjusted to $6.50 \pm 0.03$ with $\mathrm{HCl}$, and the final concentration was adjusted to $10 \mathrm{~g}$ of powder. $\mathrm{kg}^{-1}$.

\subsection{Color analyses of the powders}

Powder color was measured before and after DH using the CR-300 Chroma meter (Minolta, Roissy, France). The color values were expressed as $L^{*}$ (whiteness), $a^{*}$ (redness/greenness) and $b^{*}$ (yellowness/ blueness) and the browning index (BI) was obtained according to Maskan (2001) as follows:

$B I=\frac{[100(x-0.31)]}{0.17}$

where $\mathrm{x}=\frac{\left(a^{*}+1.75 L^{*}\right)}{\left(5.645 L^{*}+a^{*}-3.012 b^{*}\right)}$

\subsection{Marker of the Maillard reaction}

Levels of CML were determined using the method of Niquet-Léridon and Tessier (2011). Analyses were done in duplicate. Briefly, powders (amounts equivalent to $10 \mathrm{mg}$ of protein) were reduced with $1.5 \mathrm{~mL}$ of borate buffer ( $200 \mathrm{mM}, \mathrm{pH} 9.5)$ and $1 \mathrm{~mL}$ of sodium borohydride (1 M in $0.1 \mathrm{M} \mathrm{NaOH}$ ) at room temperature for $4 \mathrm{~h}$. Hydrolysis was then carried out in $6 \mathrm{~N}$ hydrochloric acid at $110^{\circ} \mathrm{C}$ for $20 \mathrm{~h}$. Hydrolysates were vacuum-dried and the dry residues were reconstituted in $20 \mathrm{mM}$ NFPA containing the internal standard (D2)-CML. After filtration through a $0.45 \mu \mathrm{m}$ filter, samples were analyzed by liquid chromatography (TSQ Vantage, Thermo Fisher Scientific, Courtaboeuf, France) (LC) coupled with tandem mass spectrometry (LC-MS/MS). Quantification of CML was achieved by measuring its peak ratio relative to the corresponding internal standard and by comparison with a calibration curve. The linear range of CML was $1-200 \mathrm{ng} \cdot \mathrm{mL}^{-1}$.

\subsection{Determination of the powder granular size distribution}

The granular size distribution of the unheated powder was analyzed using the QICPIC $^{\mathrm{TM}}$ analyzer (Sympatec GmbH, Clausthal-Zellerfeld, Germany) equipped with the dry disperser RODOS/L module (Sympatec $\mathrm{GmbH}$ ). An M6 lens was used, allowing measurements of particle size of between 5 and $1705 \mu \mathrm{m}$. Millions of particles were evaluated during $30 \mathrm{~s}$ of acquisition with a frequency of acquisition of $450 \mathrm{~Hz}$. Dynamic image analysis was performed using a special pulsed light source and a special imaging objective and a high speed camera with $1024 \times 1024$ pixels ${ }^{2}$, allowing real-time image analysis. Triplicate measurements of the distribution of the "diameter of a circle of equal projection area" of particles or EQPC were taken for each sample.

\subsection{Optical density at $500 \mathrm{~nm}$ of suspensions of whey protein microparticles}

Optical density at $500 \mathrm{~nm}\left(\mathrm{OD}_{500}\right)$ of the suspensions of WPM was measured using the UVmc2 spectrometer (SAFAS, Monaco) and plastic cuvettes with an optical path length of $1 \mathrm{~cm}$. Samples were diluted with distilled water until the $\mathrm{OD}_{500}$ was $\leq 0.8$. Measurements for each sample were repeated five times.

\subsection{Denaturation of whey proteins}

A means to evaluate the denaturation of whey proteins is to determine the acid-soluble contents after adjustment to $\mathrm{pH} 4.6$ and filtration or centrifugation of the mixture. Aliquots $(1 \mathrm{~mL})$ of the suspensions of WPM ( $10 \mathrm{~g}$ of powder. $\mathrm{kg}^{-1}$ ) were acidified by addition of $300 \mu \mathrm{L}$ of $0.5 \mathrm{M}$ acetate-acetic acid buffer ( $\mathrm{pH} 4.6$ ), and then centrifuged for $15 \mathrm{~min}$ at $10000 \mathrm{~g}$ in order to recover residual native proteins in the supernatants. The small fraction of casein present in the suspension was partitioned into the pellet during this process, as casein is not soluble at $\mathrm{pH}$ 4.6. Supernatants were then frozen until analysis. The levels of native WPs, $\beta$-Lg and $\alpha$-lac, in the supernatants were quantified by reversed phase high performance liquid chromatography 
(HPLC, Waters Alliance, Guyancourt, France) using a Vydac C4 column $(214 \mathrm{TP} 5215,150 \times 2.1 \mathrm{~mm})$. After thawing, supernatants were diluted 10 -fold in a solution of $0.106 \%$ TFA (buffer A). Samples $(100 \mu \mathrm{L}$ ) were injected onto the column at a flow of $0.2 \mathrm{~mL} \cdot \mathrm{min}^{-1}$. An acetonitrile gradient of buffer A and buffer B (acetonitrile $+0.1 \%$ TFA) was generated as follows: equilibration of the column with $28 \%$ buffer B, followed by a linear gradient from 28 to $49.6 \%$ buffer B over $40 \mathrm{~min}$ and a linear gradient from 49.6 to $80 \%$ buffer B over $1 \mathrm{~min}$, then $80 \%$ buffer B over $3 \mathrm{~min}$, followed by a decrease to $28 \%$ buffer B over $1 \mathrm{~min}$ and $28 \%$ buffer B over $5 \mathrm{~min}$. Proteins were detected at $214 \mathrm{~nm}$. Two $\beta$ $\mathrm{Lg}$ and $\alpha$-lac standards were prepared at 1.13 and 1.03 g.L ${ }^{-1}$, respectively. Concentrations were checked by measuring the optical density at $280 \mathrm{~nm}$ using extinction coefficients of 0.96 and $2.01 \mathrm{~L} . \mathrm{g}^{-1} . \mathrm{cm}^{-1}$, respectively. Native WP content was calculated as the sum of the contents of $\beta$ - $\mathrm{Lg}$ and $\alpha$-lac.

\subsection{Analysis of the microstructure of whey protein microparticles by confocal microscopy}

Suspensions of WPM were diluted 10-fold in distilled water. Aliquots of the diluted sample $(30 \mu \mathrm{L})$ were deposited on a glass lamella with $10 \mu \mathrm{L}$ of $1 \%(\mathrm{w} / \mathrm{w})$ Nile Blue. Samples were observed with a TE2000-E inverted confocal laser scanning microscope (CLSM) equipped with a Nikon $\times 20$ oil-immersion objective and a Nikon C1Si imaging system (Nikon, Champigny-sur-Marne, France). A He-Ne laser with an excitation wavelength of $632 \mathrm{~nm}$ was used at $51 \%$ power. Emitted light was recorded at $650 \mathrm{~nm}$. Images were acquired at a distance of $5 \mu \mathrm{m}$ away from the lamella using the EZ-C1 software, version 3.40 (Nikon), at a pixel resolution of $512 \times 512$, representing a spatial resolution of $636 \times 636 \mu \mathrm{m}^{2}$.

\subsection{Analysis of the clarification of suspensions of whey protein microparticles}

Clarification of the suspensions of WPM, resulting from sedimentation of particles over time, was followed using a light transmission method (Turbiscan ${ }^{\mathrm{TM}}$ LAB, Formulaction, Toulouse, France). Approximately $20 \mathrm{~mL}$ of suspension $\left(10 \mathrm{~g}\right.$ of powder. $\mathrm{kg}^{-1}$ ) were transferred to a measurement cell with a diameter of around $2.5 \mathrm{~cm}$ and a filling height of around $4 \mathrm{~cm}$. Measurements of the transmission were carried out at $20^{\circ} \mathrm{C}$ over $2 \mathrm{~h}$. Transmissions are expressed in percents due to the supplier calibration. The transmission value at the half height of the tube was plotted against the clarification time and the slope of the increase in transmission between 10 and 120 min was determined in $\%$. min $^{-1}$. Differences in suspension viscosity between samples of suspensions of WPM were only slight and were not taken into account for this analysis.

\subsection{Yield of conversion of the powder material into the WPM and water content of the WPMformed}

Fractions containing $2 \mathrm{~g}$ of a suspension of WPM were centrifuged at $10000 \mathrm{~g}$ for $15 \mathrm{~min}$ in order to recover the pellet containing sedimented WPM. The weights of these pellets were calculated in $g$ for an equivalent of $100 \mathrm{~g}$ of suspension (WY). The pellets were then dried, using a Savant Speed Vac Concentrator SVC-100H (Hicksville, USA), for $13 \mathrm{~h}$ with heating at $45^{\circ} \mathrm{C}$. The dried pellets were then weighed and the dry weight was calculated in $\mathrm{g}$ for an equivalent of $100 \mathrm{~g}$ of suspension (DY). As $100 \mathrm{~g}$ of a suspension of WPM contained $1 \mathrm{~g}$ of dry-heated powder, WY and DY represented the dry and wet yields of conversion of the powder material into WPM in $\mathrm{g} / \mathrm{g}$.

The water content (WC) or amount of water entrapped in the pellet was calculated as follows:

$W C\left(\frac{g}{g}\right.$ of dry WPM $)=\frac{(W Y-D Y)}{D Y}$

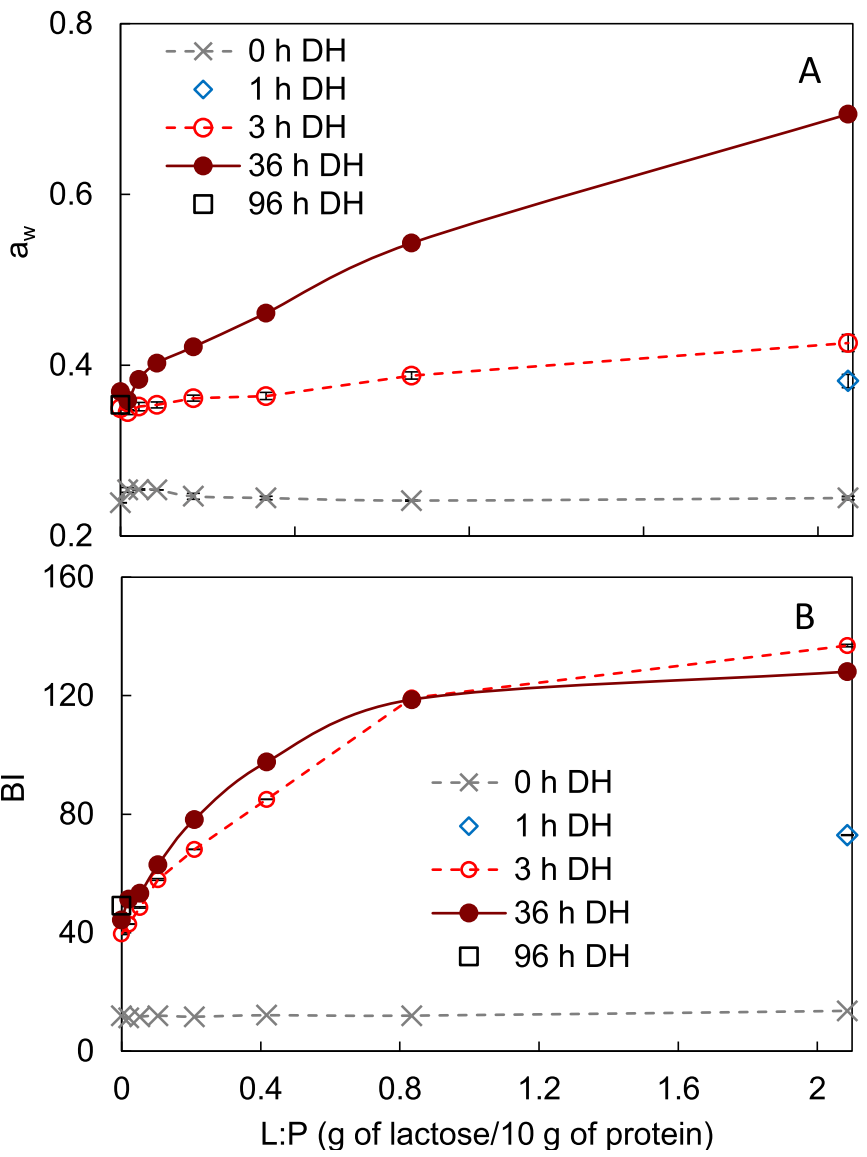

Fig. 1. Water activity and browning index (BI) as a function of added lactose and time of dry heating at $100{ }^{\circ} \mathrm{C}$. A: water activity $\left(\mathrm{a}_{\mathrm{w}}\right)$, and $\mathrm{B}$ : browning index (BI). Quantities of lactose are presented as the ratio of lactose added in $\mathrm{g}$ to $10 \mathrm{~g}$ of protein (L:P $=0-2.09 \mathrm{~g} / 10 \mathrm{~g}$ ).

Measurements were performed four times for each suspension of WPM.

\subsection{Statistical analysis}

The effect of the different treatments on the CML content was studied by an analysis of variance (ANOVA). Tukey's multiple comparison tests were used for paired comparisons of means. $\mathrm{P}<0.05$ was used as the level of significance. All statistical analyses were performed using the $\mathrm{R}$ software package.

\section{Results}

\subsection{Powder characterization}

The $\mathrm{a}_{\mathrm{w}}$ of powders increased with the time of DH between 0 and $36 \mathrm{~h}$ and with increases in the L:P (Fig. 1A). For L:P $=0 \mathrm{~g} / 10 \mathrm{~g}$, the $\mathrm{a}_{\mathrm{w}}$ of the powder increased by a factor of 1.5 after $3 \mathrm{~h}$ of $\mathrm{DH}$, but no further changes in $\mathrm{a}_{\mathrm{w}}$ were observed after more prolonged $\mathrm{DH}$. This indicates that for $\mathrm{L}: \mathrm{P}=0 \mathrm{~g} / 10 \mathrm{~g}$ the change in $\mathrm{a}_{\mathrm{w}}$ was complete after $3 \mathrm{~h}$ of DH. With lactose addition, the $\mathrm{a}_{\mathrm{w}}$ continued to increase between 3 and $36 \mathrm{~h}$ of DH. An increase was also observed between $1 \mathrm{~h}$ and $3 \mathrm{~h}$ of DH for $\mathrm{L}: \mathrm{P}=2.09 \mathrm{~g} / 10 \mathrm{~g}$. After $36 \mathrm{~h}$ of $\mathrm{DH}$, the increase in $\mathrm{a}_{\mathrm{w}}$ with increasing L:P seemed to show a linear trend. Although the maximum $\mathrm{a}_{\mathrm{w}}$ value of 1 was not obtained, a very high $\mathrm{a}_{\mathrm{w}}$ value close to 0.7 was obtained after $36 \mathrm{~h}$ of DH for $\mathrm{L}: \mathrm{P}=2.09 \mathrm{~g} / 10 \mathrm{~g}$, but individual flakes of powder could still be observed.

The BI also increased with increasing L:P and after DH, but this 


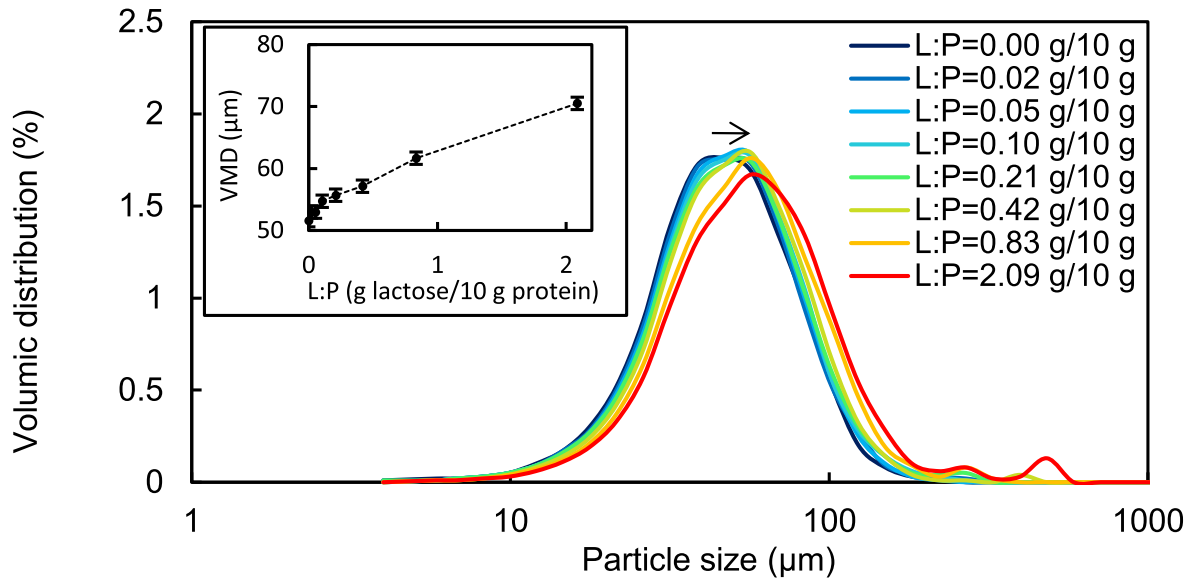

Fig. 2. Granular size distribution of the unheated powder as a function of added lactose ( $\mathrm{L}: \mathrm{P}$ in $\mathrm{g}$ lactose $/ 10 \mathrm{~g}$ of protein). The particle size distribution is expressed as a percentage of volume as measured by the QICPIC method. The arrow highlights the slight shift of the distribution to the right. Inset: changes in the volume mean diameter (VMD) of powder particles as a function of added lactose. increase was complete after $3 \mathrm{~h}$ of $\mathrm{DH}$ or even before, regardless of the amount of lactose added (Fig. 1B). The largest increases in BI with increasing L:P were observed when the L:P was between $0 \mathrm{~g} / 10 \mathrm{~g}$ and $0.83 \mathrm{~g} / 10 \mathrm{~g}$, whereas the $\mathrm{BI}$ appeared to plateau at around $\mathrm{L}: \mathrm{P}=1.5 \mathrm{~g}$ / $10 \mathrm{~g}$. After only $1 \mathrm{~h}$ of $\mathrm{DH}$ at the maximum value of L:P tested, the powder was browner and darker than powders without added lactose that had been dry heated for 3,36 or $96 \mathrm{~h}$. The addition of lactose dramatically increased powder browning to a maximum value obtained after $3 \mathrm{~h}$ of $\mathrm{DH}$. Once this maximum value had been reached, no more color changes occurred in the dry-heated powders. The pattern of changes in the color of the powders with increasing levels of lactose seemed to differ from the pattern observed for the $\mathrm{a}_{\mathrm{w}}$.

The granular size distribution of the unheated powder is shown in Fig. 2. The size of the powder flakes varied between around 5 and $300 \mu \mathrm{m}$. The volume mean diameter (VMD) of the distribution was $51.69 \pm 0.65 \mu \mathrm{m}$ without added lactose. The addition of lactose led to an increase in the VMD to $70.51 \pm 0.06 \mu \mathrm{m}$ for $\mathrm{L}: \mathrm{P}=2.09 \mathrm{~g} / 10 \mathrm{~g}$ (Fig. 2, inset).

\subsection{Carboxymethyllysine content}

The CML content of the initial WP powder and those of the powders dry heated in the presence and absence lactose are shown in Table 1. The initial WP powder already contained CML. Preparation of the powder with added lactose up until the point of $\mathrm{DH}$, including solubilization of the powder in a lactose solution at $\mathrm{L}: \mathrm{P}=0.83 \mathrm{~g} / 10 \mathrm{~g}$ and $\mathrm{pH}$ and $\mathrm{a}_{\mathrm{w}}$ adjustments, increased the CML content by around 3.5-fold. DH for $3 \mathrm{~h}$ led to a further increase in CML content at $\mathrm{L}: \mathrm{P}=0.83 \mathrm{~g} / 10 \mathrm{~g}$, after which the CML levels plateaued with no statistically significant differences in CML content between the powder dry heated for $3 \mathrm{~h}$ and that which was dry heated for $36 \mathrm{~h}$. The CML content in the $\mathrm{L}: \mathrm{P}=0.83 \mathrm{~g} / 10 \mathrm{~g}$ after $36 \mathrm{~h}$ of DH was more than two-fold higher than that of the powder dry heated for $36 \mathrm{~h}$ in the absence of lactose. The

\section{Table 1}

Carboxymethyllysine content (CML) in $\mathrm{ng} / \mathrm{mg}$ of protein in powders before and after dry heating at $100{ }^{\circ} \mathrm{C}$.

\begin{tabular}{ll}
\hline Powder & CML (ng/mg protein) \\
\hline WP starting powder & $162 \pm 11^{\mathrm{a}}$ \\
$36 \mathrm{~h}$ of DH without added lactose & $1599 \pm 138^{\mathrm{b}}$ \\
$0 \mathrm{~h}$ of DH with lactose at L:P $=0.83 \mathrm{~g} / 10 \mathrm{~g}$ protein* & $559 \pm 65^{\mathrm{c}}$ \\
$3 \mathrm{~h}$ of DH with lactose at L:P $=0.83 \mathrm{~g} / 10 \mathrm{~g}$ protein & $4297 \pm 34^{\mathrm{d}}$ \\
$36 \mathrm{~h}$ of DH with lactose at L:P $=0.83 \mathrm{~g} / 10 \mathrm{~g}$ protein & $4013 \pm 16^{\mathrm{d}}$
\end{tabular}

*The $\mathrm{a}_{\mathrm{w}}$ of this powder was adjusted to $\sim 0.25$.

a,b,c,d Indicate samples with statistically significant differences in CML content $(\mathrm{P}<0.05)$.

CML: Carboxymethyllysine; DH, dry heating; WP, whey protein. pattern of increase in CML content after DH in the presence of lactose is similar to the pattern observed for the color changes of the powders, and a linear regression was found between these 2 variables $(\mathrm{P}<0.01)$. CML is one of the AGE that were produced during the Maillard reaction, together with many other AGE such as Pyrraline or formyl lysine (Soboleva, Schmidt, Vikhnina, Grishina, \& Frolov, 2017).

\subsection{Level of whey protein denaturation}

The level of native WPs in suspensions of WPM as a function of added lactose and time of DH is shown in Fig. 3. It should be noted that preparation of the powders led to only partial protein denaturation; therefore, suspensions of dry-heated powder were mixed systems, with some of the proteins dispersed as WPM and some in a true protein solution. Moreover, it should be kept in mind that if whey proteins were polymerized in large entities but still native or native-like, they would be present in the pellet and recorded as non-native. $\mathrm{DH}$ is indeed known to induce low denaturation levels as compared to heating in the liquid state, because of the high value of the denaturation temperature at an $\mathrm{a}_{\mathrm{w}}$ value such as 0.23 . Also the fact that protein are part of the AGE could reduce their native-like nature (Gerrard, 2006). In the powder at $\mathrm{L}: \mathrm{P}=0 \mathrm{~g} / 10 \mathrm{~g}$, adjusted to $\mathrm{a}_{\mathrm{w}} \sim 0.25$ and at $0 \mathrm{~h}$ of $\mathrm{DH}$, the extent of denaturation was low, at around 30\%. The levels of denaturation of WP at $0 \mathrm{~h}$ of DH appeared to be lower at high L:P than at low L:P. However, as can be seen in Fig. 3B, the protein peaks for the unheated powder are not well defined. For instance, the two peaks of $\beta$ - Lg seen before $\mathrm{DH}$ at $\mathrm{L}: \mathrm{P}=0 \mathrm{~g} / 10 \mathrm{~g}$ became a single larger peak at $\mathrm{L}: \mathrm{P}=2.09 \mathrm{~g} / 10 \mathrm{~g}$. Moreover, there are doubts over the accuracy of the integration of these curves as the quantification of $\beta-\mathrm{Lg}$ and $\alpha$-lac was based on the known values of the extinction coefficients for these proteins before modification but these values after modification are unknown. Proteins were considered as native, because they were still soluble at $\mathrm{pH} 4.6$, but these proteins were likely to have been already modified by the preparation procedure. The observed reductions and increases in the retention times of the proteins could be explained by the proteins becoming more hydrophilic as a result of protein glycation, or more hydrophobic, respectively. Denaturation of WPs increased with the time of $\mathrm{DH}$ and with the addition of lactose when the powder was dry heated: no native proteins remained after $3 \mathrm{~h}$ of DH at L:P $=2.09 \mathrm{~g} / 10 \mathrm{~g}$ (Fig. 3B, sample 4), whereas native proteins were still present at $\mathrm{L}: \mathrm{P}=0 \mathrm{~g} / 10 \mathrm{~g}$ (Fig. 3B, sample 3). No native proteins were detected in any of the powders with $\mathrm{L}: \mathrm{P}>0.83 \mathrm{~g} / 10 \mathrm{~g}$ after $3 \mathrm{~h}$ of DH (Fig. $3 \mathrm{~A}$ ). The levels of native $\beta$ - $\mathrm{Lg}$ and $\alpha$-lac decreased at the same rate (data not shown). This pattern of behavior seems to differ from both the pattern of color changes and that of the changes in $\mathrm{a}_{\mathrm{w}}$. 

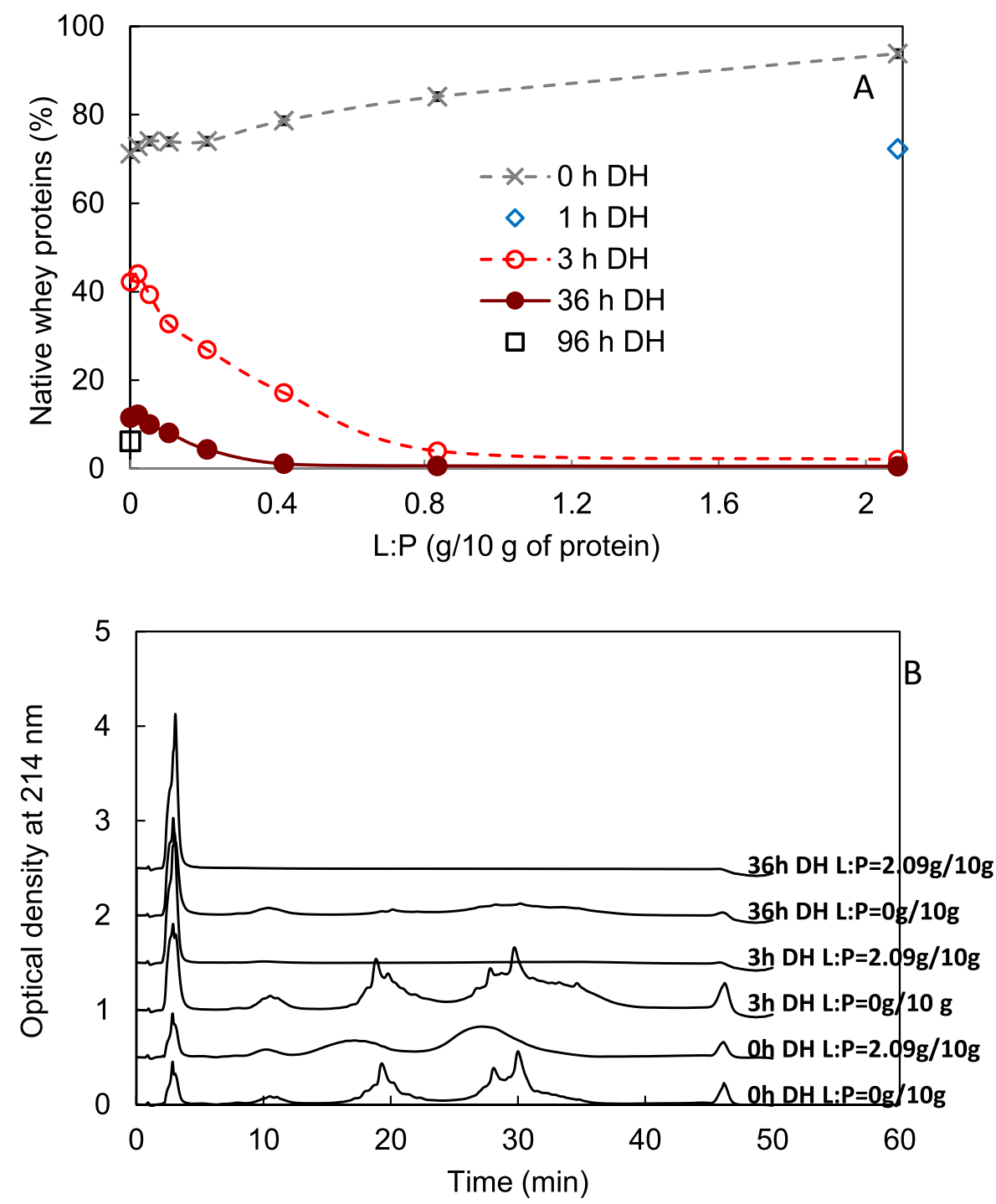

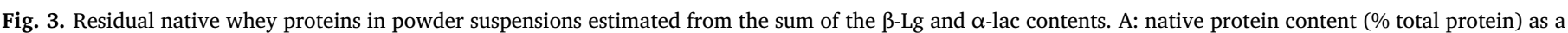

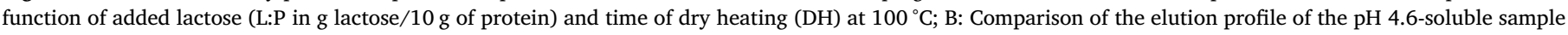
fractions.

\subsection{Characterization of suspensions of whey protein microparticles}

The $\mathrm{OD}_{500 \mathrm{~nm}}$ of suspensions of dry-heated powders as a function of $\mathrm{L}: \mathrm{P}$ is shown in Fig. 4. The $\mathrm{OD}_{500 \mathrm{~nm}}$ of suspensions increased with the time of DH between 3 and $36 \mathrm{~h}$. It also increased with increases in the concentration of added lactose until reaching a maximum at $\mathrm{L}: \mathrm{P}=0.83 \mathrm{~g} / 10 \mathrm{~g}$ after $3 \mathrm{~h}$ of $\mathrm{DH}$ and at $\mathrm{L}: \mathrm{P}=0.42 \mathrm{~g} / 10 \mathrm{~g}$ after $36 \mathrm{~h}$ of $\mathrm{DH}$. For the powder at $\mathrm{L}: \mathrm{P}=0 \mathrm{~g} / 10 \mathrm{~g}$, the $\mathrm{OD}_{500 \mathrm{~nm}}$ of the suspension after $96 \mathrm{~h}$ of DH of was approximately two-fold higher than that after $36 \mathrm{~h}$ of $\mathrm{DH}$. The $\mathrm{OD}_{500 \mathrm{~nm}}$ changes could be related to changes in the volume fraction (number and/or size) of particles and to changes in their optical properties, such as their refractive index.

The CLSM micrographs of the WPM are shown in Fig. 5. No particles were visible in the suspensions of powders at $0 \mathrm{~h}$ of dry heating, even at a much higher magnification such as $\times 100$ (data not shown). Very low quantities of WPM were observed in suspensions of powders after DH for $3 \mathrm{~h}$ at $\mathrm{L}: \mathrm{P} \leq 0.05 \mathrm{~g} / 10 \mathrm{~g}$ and for those after $\mathrm{DH}$ for $1 \mathrm{~h}$ at $\mathrm{L}: \mathrm{P}=2.09 \mathrm{~g} / 10 \mathrm{~g}$. For all other samples, a high content of WPM was found. The number of particles present after $3 \mathrm{~h}$ of DH increased when the L:P increased from 0 to $0.8 \mathrm{~g} / 10 \mathrm{~g}$. Moreover, CLSM provided information about the morphology of the WPM. The size of the WPM was very heterogeneous, ranging from approximately 3 to $100 \mu \mathrm{m}$. WPM

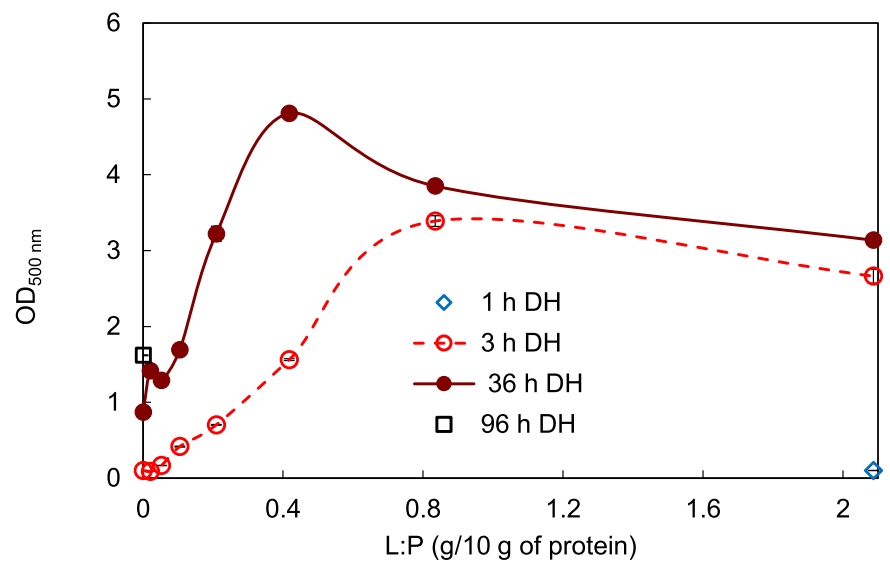

Fig. 4. Optical density measured at $500 \mathrm{~nm}\left(\mathrm{OD}_{500 \mathrm{~nm}}\right)$ of powder suspensions as a function of added lactose (L:P in $\mathrm{g}$ lactose $/ 10 \mathrm{~g}$ of protein) and time of dry heating at $100{ }^{\circ} \mathrm{C}$.

had very angular shapes, as flakes of freeze-dried powder particles. Sedimentation was found to be a special feature of the WPM, 

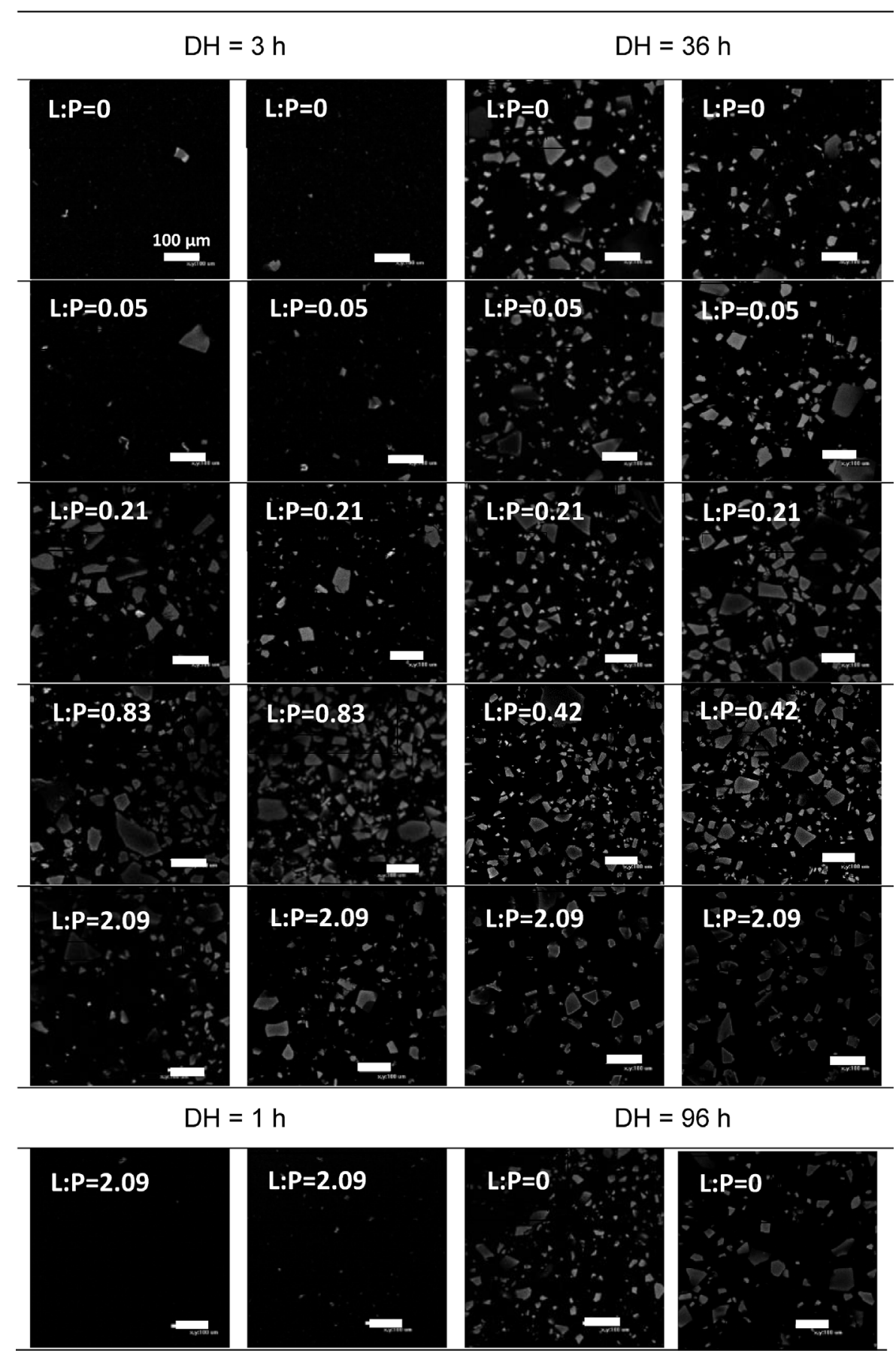

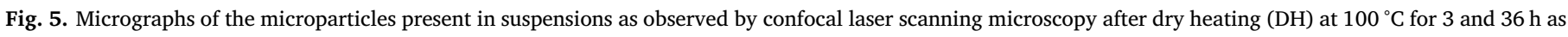

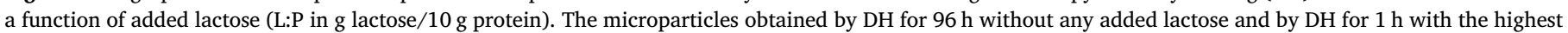
level of added lactose ( $\mathrm{L}: \mathrm{P}=2.09 \mathrm{~g} / 10 \mathrm{~g}$ ) are also shown. The bar represents $100 \mu \mathrm{m}$. Two representative micrographs are shown for each set of conditions.

occurring due to the very large size of these particles. Images of suspensions prepared with powders after $\mathrm{DH}$ for $36 \mathrm{~h}$ and then storage for 2 weeks at $20^{\circ} \mathrm{C}$ in quiescent conditions are shown in Fig. 6A. At a high $\mathrm{L}: \mathrm{P}$, the volume occupied by the WPM was considerably smaller than at a lower value of L.P. This reduction of the volume fraction of WPM could probably explain the large reduction in the $\mathrm{OD}_{500 \mathrm{~nm}}$ observed in Fig. 4 after $36 \mathrm{~h} \mathrm{DH}$ at L:P $>0.4 \mathrm{~g} / 10 \mathrm{~g}$. Also, the brown color became darker as the L:P increased. The speed of clarification seemed to decrease slightly between $\mathrm{L}: \mathrm{P}=0 \mathrm{~g} / 10 \mathrm{~g}$ and $0.41 \mathrm{~g} / 10 \mathrm{~g}$, and then sharply increased to a maximum at $\mathrm{L}: \mathrm{P}=2.09 \mathrm{~g} / 10 \mathrm{~g}$ (Fig. 6B).

\subsection{Yield of conversion and water content of the whey protein} microparticles formed

As observed by CLSM, almost no WPM were formed from powders at $\mathrm{L}: \mathrm{P}<0.02 \mathrm{~g} / 10 \mathrm{~g}$ after $3 \mathrm{~h}$ of $\mathrm{DH}$, or from the powder heated for only $1 \mathrm{~h}$ at the maximum L:P of $2.09 \mathrm{~g} / 10 \mathrm{~g}$. Accordingly, very low DYs of conversion were obtained for powders dry heated for $3 \mathrm{~h}$ at the lowest L:P ratio, and for powders dry heated for $1 \mathrm{~h}$ at the highest L:P ratio (Fig. 7A). The low DYs value obtained after $3 \mathrm{~h}$ of $\mathrm{DH}$ at $\mathrm{L}: \mathrm{P}=0 \mathrm{~g}$ / $10 \mathrm{~g}$ in the current study $(0.05 \pm 0.01 \mathrm{~g} / \mathrm{g})$ were very close to those obtained before DH without any lactose addition $(0.04 \pm 0.01 \mathrm{~g} / \mathrm{g}$ (Famelart et al., 2018)) and could probably be due to some insoluble 

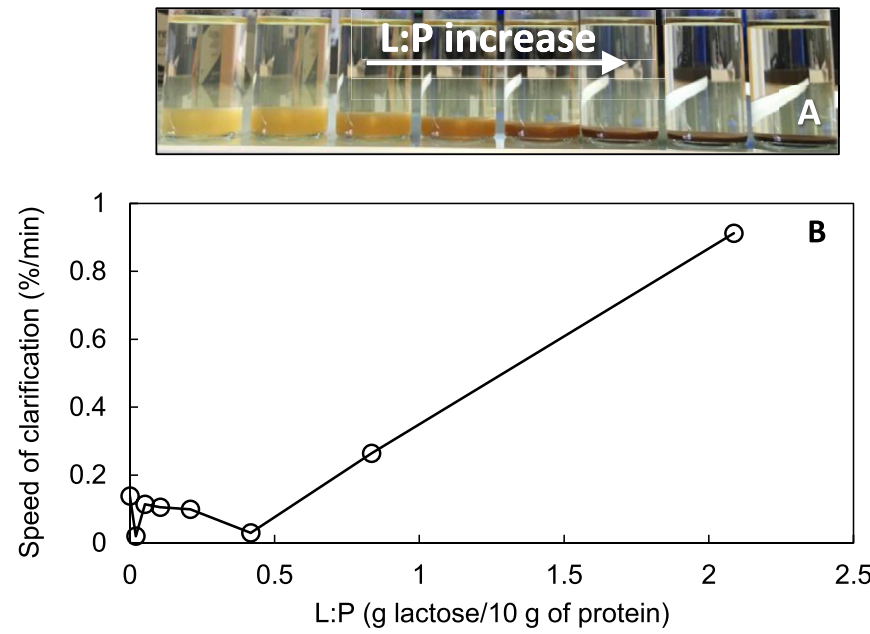

Fig. 6. Clarification of suspensions and sedimentation of whey protein microparticles produced by $36 \mathrm{~h}$ of dry heating at $100^{\circ} \mathrm{C}$ as a function of the added lactose (L:P in $\mathrm{g}$ lactose $/ 10 \mathrm{~g}$ protein). A: Photographs of powder suspensions after 15 days of sedimentation at $20^{\circ} \mathrm{C}$. B: Rate of clarification of the suspensions in $\% \cdot \mathrm{min}^{-1}$.

material coming from the powder. In the absence of any added lactose, the DY of conversion was almost $0.7 \mathrm{~g} / \mathrm{g}$ after $36 \mathrm{~h}$ of DH, whereas it was around 0 after $3 \mathrm{~h}$ of DH. As the L:P increased, the DY of conversion increased until a plateau value was reached close to 1 (Fig. 7A). This indicates that an almost total conversion of the powder material into the WPM occurred under these preparation conditions, with a maximal value of $0.98 \mathrm{~g} / 1 \mathrm{~g}$ of powder after $36 \mathrm{~h}$ of DH at a $\mathrm{L}: \mathrm{P} \sim 0.4 \mathrm{~g} / 10 \mathrm{~g}$. It also indicates that casein, representing $18 \%$ of the proteins of the WP powder, was incorporated into the WPM. For $3 \mathrm{~h}$ and $36 \mathrm{~h}$ of DH, the plateau values were reached at $\mathrm{L}: \mathrm{P} \sim 0.8 \mathrm{~g} / 10 \mathrm{~g}$ and at $\sim 0.4 \mathrm{~g} / 10 \mathrm{~g}$, respectively. It appears that the plateau value after $3 \mathrm{~h}$ of $\mathrm{DH}$ was slightly lower than that after $36 \mathrm{~h}$ of DH and that these values decreased slightly with the increase in the L:P towards the highest values. This pattern of behavior appears to be similar to the patterns observed for the native proteins and for the turbidity changes: at L:P $<0.8 \mathrm{~g} / 10 \mathrm{~g}$, the reaction was not complete after $3 \mathrm{~h}$ of $\mathrm{DH}$ and went on evolving, whereas at higher L:P values, the reaction was so rapid that it was complete after $3 \mathrm{~h}$ of $\mathrm{DH}$.

The WPM had maximum values of WC around $42 \mathrm{~g} / \mathrm{g}$ powder. Such high values were mainly due to capillary and hydrodynamic hydration water held in the macroparticle structure, or loosely surrounding it, as the water bound to proteins is much lower: water binding capacity of $\beta$ $\mathrm{Lg}$ amounts to $0.3 \mathrm{~g} / \mathrm{g}$ (Kneifel \& Seiler, 1993). The WC of the WPM decreased as the L:P increased (Fig. 7B). The WPM became less hydrated and denser as the lactose content increased and the time of $\mathrm{DH}$ increased. After $3 \mathrm{~h}$ of $\mathrm{DH}$, with L:P values $<0.2 \mathrm{~g} / 10 \mathrm{~g}, 1 \mathrm{~g}$ of WPM were able to retain around 30 times their weight in water, but these values declined to around $5-10 \mathrm{~g}$ at $\mathrm{L}: \mathrm{P}>0.81 \mathrm{~g} / 10 \mathrm{~g}$. This pattern of behavior was related to that observed for the DY: the higher the DY, the lower the water content.

As the DY of conversion increased and the WC decreased with the increasing L:P ratio, the WY of WPM could be expected to increase or decrease with the increase in L:P. After $3 \mathrm{~h}$ of $\mathrm{DH}$, an increase in L:P of up to $0.2-0.4 \mathrm{~g} / 10 \mathrm{~g}$ led to a gain in the WY, and then to a decline at higher L:P values, whereas after $36 \mathrm{~h}$ of $\mathrm{DH}$, the WY first stayed constant and then declined for $\mathrm{L}: \mathrm{P}>0.05 \mathrm{~g} / 10 \mathrm{~g}$ (Fig. $7 \mathrm{C}$ ).

In conclusion, at $\mathrm{L}: \mathrm{P}=0.42 \mathrm{~g} / 10 \mathrm{~g}$ after $3 \mathrm{~h}$ of dry heating, the DY of WPM was close to the value reached after $36 \mathrm{~h}$ of DH without lactose, with values for the WC and WY being more or less equivalent after $3 \mathrm{~h}$ of dry heating with L:P $=0.42 \mathrm{~g} / 10 \mathrm{~g}$ and after $36 \mathrm{~h}$ without lactose addition. Addition of lactose allowed shortening the process of WPM production.
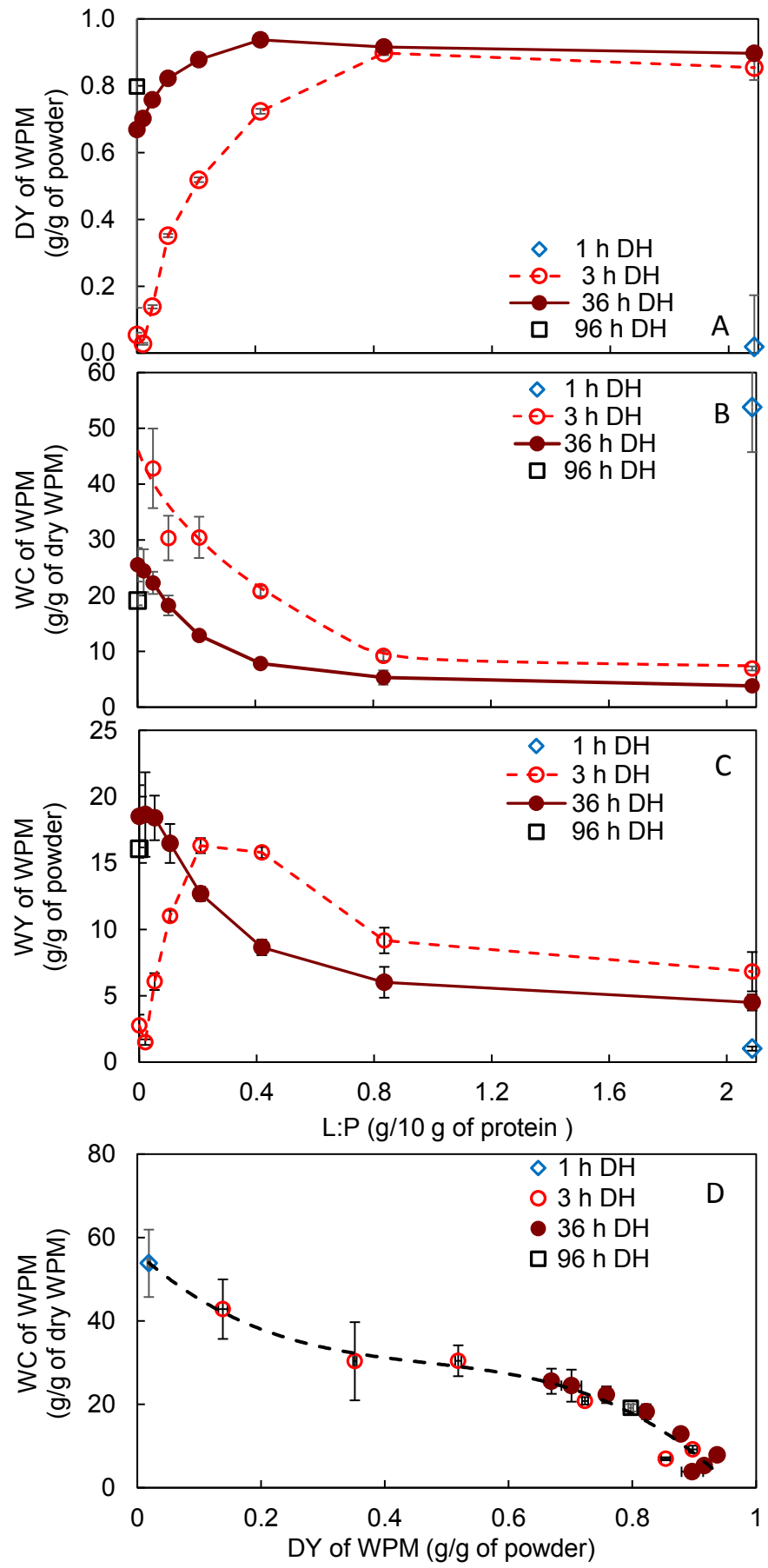

Fig. 7. Yield of conversion of the powder into the whey protein microparticles (WPM) and water content of the WPM as a function of added lactose (L:P in $g$ lactose $/ 10 \mathrm{~g}$ protein) and time of dry heating at $100^{\circ} \mathrm{C}$. Pellets of WPM were obtained by centrifugation of suspensions at $10000 \mathrm{~g}$ for $15 \mathrm{~min}$ at $20^{\circ} \mathrm{C}$. A: Dry yield of conversion (DY) of WPM recovered in the pellet for $1 \mathrm{~g}$ of powder (in $\mathrm{g} /$ $\mathrm{g}$ ); B: Water content (WC) of the WPM in $\mathrm{g}$ per $1 \mathrm{~g}$ of dry WPM; C: Wet yield of conversion (WY) of WPM recovered in the pellet for $1 \mathrm{~g}$ of powder (in $\mathrm{g} / \mathrm{g}$ ). D: Relationship between the DY and the WC.

It should be noted that when the DY of conversion into WPM increased, the WC of WPM decreased (Fig. 7D), and that the relationship was not linear. The increase of the DY from 0.7 to $0.9 \mathrm{~g} / \mathrm{g}$ led to a stronger reduction of the WC of WPM. 


\section{Discussion}

Our study shows that $\mathrm{DH}$ at $100{ }^{\circ} \mathrm{C}$ for 3 or $36 \mathrm{~h}$ of a WP powder conditioned at $\mathrm{pH} 9.5$ led to the production of large and highly hydrated WPM. Addition of lactose increased the rate of production of these WPM.

First of all, the size of the unheated powder flakes was larger when the L:P was increased (Fig. 2). We suspect that the powder was more rigid in the presence of lactose and consequently it was more difficult to crush into small flakes. Lactose in powders produced by freeze-drying is prone to crystallization and is known to be very difficult to crush (Schuck, private communication). This could explain the increase in the size of the flakes with lactose addition.

The DH of WP powders at $100{ }^{\circ} \mathrm{C}$ in the presence of increasing contents of lactose led to more intense browning of the powder and to increases in CML content (Fig. 1, Table 1). These changes were due to the MR. CML is one of the AGEs of the MR, and is considered as an important marker of the reaction. Another consequence of the MR is the formation of brown melanoidins, responsible for powder browning (Manzocco, Calligaris, Mastrocola, Nicoli, \& Lerici, 2000). Thus, browning of the powder is a simple indicator of the intensity of the MR. The MR is a very complex reaction initiated by the interaction between a reducing sugar, lactose in case of our current study, and amino groups of the protein chains (Maillard, 1912). Studies on heated model mixtures have shown that water molecules are produced during this reaction (Manzocco \& Maltini, 1999). We also observed an increase in $a_{w}$, thought to be due to the MR (Fig. 1). Our study of the BI indicated that the MR was complete after $3 \mathrm{~h}$ or less of $\mathrm{DH}$, regardless of the amount of added lactose. Measurements of CML content may also have revealed a similar pattern, but we did not measure CML levels in powders with varying lactose contents. However, we found that the $\mathrm{a}_{\mathrm{w}}$ of the powders went on increasing beyond $3 \mathrm{~h}$ of $\mathrm{DH}$ with added lactose, indicating that the increase in $\mathrm{a}_{\mathrm{w}}$ was not solely related to the progress of the MR. We do not have any hypothesis for this increase in $a_{w}$.

Our results show that adding lactose results in a more intensive MR at any given time of $\mathrm{DH}$, as shown by the increase in BI. Moreover, our measurements of CML content show that the MR occurred before any DH of the powder. Data from previous studies suggest that this reaction could have taken place when the $\mathrm{pH}$ of the WP solution was adjusted to $\mathrm{pH} 9.5$ and/or during the adjustment of the $\mathrm{a}_{\mathrm{w}}$ of the powders at $20^{\circ} \mathrm{C}$ for two weeks. The MR may have occurred during the $\mathrm{pH}$ adjustment because the reactivity between the sugar and the nucleophilic amino groups is higher in alkaline environments (Martins et al., 2000). Although it is well known that the MR progresses very slowly in liquids, it does progress during the storage of WP powders, as shown in a previous study which revealed a doubling of the level of protein lactosylation and a $2 \%$ loss of $\beta$ - $\mathrm{Lg}$ monomers in favour of polymers after 3-month storage of a WP powder with an $\mathrm{a}_{\mathrm{w}}=0.23$ at $20^{\circ} \mathrm{C}$ (Norwood et al., 2016). In our study, adding lactose probably also increased the content of undesirable AGE, as it did for CML, but further studies are required to investigate these products.

The $\mathrm{OD}_{500 \mathrm{~nm}}$ increased with the L:P due to the formation of WPM, until a critical value of $\mathrm{L}: \mathrm{P}\left(\mathrm{L}: \mathrm{P}_{\text {crit }}\right)$ was reached. The $\mathrm{L}: \mathrm{P}_{\text {crit }}$ was $0.8 \mathrm{~g} /$ $10 \mathrm{~g}$ after $3 \mathrm{~h}$ of DH and $0.4 \mathrm{~g} / 10 \mathrm{~g}$ after $36 \mathrm{~h}$ of DH (Fig. 4). There appeared to be a correlation between the increase in $\mathrm{OD}_{500 \mathrm{~nm}}$ and the increase in the number of particles seen by CLSM (Fig. 5). The question arises as to why this $\mathrm{OD}_{500 \mathrm{~nm}}$ decreased after reaching the L: $\mathrm{P}_{\text {crit }}$. Our CLSM observations suggested that the number of particles remained constant above the $L: P_{\text {crit }}$. We first observed that the sedimented pellets of powders above the $\mathrm{L}: \mathrm{P}_{\text {crit }}$ had smaller fraction volumes (Fig. 6A). We also observed that the DY decreased above the L:P $\mathrm{P}_{\text {crit }}$ (Fig. 7A) and thus the WPM included a lower dry matter. A reduced volume fraction and solid content in WPM could explain the decrease in suspension $\mathrm{OD}_{500}$.

Our DY measurements showing that the DY decreased slightly above the $\mathrm{L}: \mathrm{P}_{\text {crit }}$ (Fig. 7A) indicate that less material accumulated in the WPM of these powders and that WPM had a lower solid content. We suspect that the level of degradation of substrates could increase with the content in lactose, with a concomitant increase in the production of small soluble or volatile Maillard intermediate like ammonia, diacetyl, formic or acetic acid. It is well known that at alkaline $\mathrm{pH}$ values, $50 \%$ of the degraded glucose during the dry heating of a mixture of glycine and glucose represent formic and acetic acid (Martins \& Van Boekel, 2005b). Ammonia has also been detected after the MR and is produced from cysteine residues during the Strecker reaction (Mottram, 2007). We also found that high levels of ammonia were produced when the $\mathrm{pH}$ during DH was above 9.5 (personal communication). However, the addition of lactose in solution may also explain the decrease in DY: when lactose was added in the whey protein solution, the powder contained a lower amount of protein per $g$ of powder. Indeed, if the DY are expressed per $g$ of protein instead of $g$ of powder, DY did not decrease at high L:P (Supplementary Fig. S2). At high values of L:P, the DY became $>1$, which confirmed that not only proteins were incorporated into macroparticles formed by $\mathrm{DH}$, but also protein-lactose Maillard intermediates.

It has been assumed that powder flakes become more cross-linked with increasing DH times, leading to limited swelling in water and to reduced WC (Schong \& Famelart, 2018). In fact, the crosslinking of peptide chains during the advanced steps of the MR has been reported elsewhere, either by dicarbonyl compounds such as glyoxal and methylglyoxal or by some AGE or some melanoidins (Cho, Okitani, \& Kato, 1984; Gerrard, 2006; Gerrard et al., 2005; Kato, Matsuda, Kato, \& Nakamura, 1988). The higher DY resulting from addition of lactose (Fig. 7A) was probably due to enhanced crosslinking of proteins inside the flakes. However, this increase in crosslinking may have led to even further limitation of the swelling, explaining why addition of lactose led to strong reductions in the $\mathrm{WC}$ of particles above the $\mathrm{L}: \mathrm{P}_{\text {crit }}$. In addition, phase-contrast optical microscopy of WPM produced by $36 \mathrm{~h}$ of DH showed that at L:P $=0 \mathrm{~g} / 10 \mathrm{~g}$ the WPM appeared to be transparent, probably because of a high WC and a small refractive index, whereas WPM produced at $\mathrm{L}: \mathrm{P}=2.09 \mathrm{~g} / 10 \mathrm{~g}$ appeared more opaque (not shown). A particle with a water content around $96 \%$ in weight has probably a refractive index close to that of water and would probably be transparent.

The small loss of $30 \%$ of the native WP before DH (Fig. 3) has already been reported from previous studies, and was attributed to the alkaline pH used in these studies (Famelart et al., 2018; Schong \& Famelart, 2018). This loss of native WP is related to the unfolding and polymerization of WPs above pH 9 (Monahan, German, \& Kinsella, 1995; Partanen et al., 2011; Taulier \& Chalikian, 2001). According to Famelart et al. (2018), $\beta$ - $\mathrm{Lg}$ and $\alpha$-lac are incorporated into particles formed by $\mathrm{DH}$ at $\mathrm{pH}$ 9.5. This is confirmed in the current study as $\beta-\mathrm{Lg}$ and $\alpha$-lac were both integrated into WPM, regardless of the lactose content. With added lactose, the kinetics of the denaturation of $\beta-\mathrm{Lg}$ and $\alpha$-lac were more rapid, as was the kinetics of WPM formation.

Whereas the browning of powders was complete after $3 \mathrm{~h}$ of $\mathrm{DH}$, irrespective of the lactose content, the $\mathrm{a}_{\mathrm{w}}$ went on increasing between 3 and $36 \mathrm{~h}$ of DH. There appeared to be no correlation between these two powder measurements, suggesting that $\mathrm{a}_{\mathrm{w}}$ did not only measure the progress of the MR and was not an accurate indicator of the reaction. However, it should be noted that the intensity of the MR did not correlate with the production of WPM, as the formation of WPM was not complete after $3 \mathrm{~h}$ of DH at low contents of lactose. In fact, Famelart et al. (2018) showed that DH of WP powders conditioned at pH 3.5 or $\mathrm{pH} 6.5$ leads to intense powder browning without any microparticle formation. It was only in the alkaline environment that powder browning and WPM were both observed. This highlights the fact that the MR can progress without the production of any microparticles. Between L:P $=0 \mathrm{~g} / 10 \mathrm{~g}$ and $0.8 \mathrm{~g} / 10 \mathrm{~g}$, the formation of WPM was not complete at $3 \mathrm{~h}$ of DH and went on progressing between 3 and $36 \mathrm{~h}$ of DH: the higher the L:P value, the quicker the kinetics. However, with $\mathrm{L}: \mathrm{P}$ values above $0.8 \mathrm{~g} / 10 \mathrm{~g}$, the further addition of lactose led to measurement values obtained at $3 \mathrm{~h}$ of $\mathrm{DH}$ being more or less identical 
to those obtained at $36 \mathrm{~h}$. This plateauing of the values was probably due to the fact that formation of the WPM was already complete after $3 \mathrm{~h}$ of $\mathrm{DH}$ at $\mathrm{L}: \mathrm{P}>0.8 \mathrm{~g} / 10 \mathrm{~g}$, due to the increased rapidity of the kinetics of formation of WPM at a high lactose content. Plateaus were observed for protein denaturation (Fig. 3), for OD500 of suspensions (Fig. 4), for DY and for WC. These findings show that for powders with $\mathrm{L}: \mathrm{P}$ values of above $0.8 \mathrm{~g} / 10 \mathrm{~g}$, there is no need to apply dry heat for more than $3 \mathrm{~h}$. At L:P values close to or lower than $2.09 \mathrm{~g} / 10 \mathrm{~g}$, the reaction may have been complete in much less than $3 \mathrm{~h}$, but as our measurements of yields and WC showed (Fig. 7), the reaction was not yet complete after $1 \mathrm{~h}$ of $\mathrm{DH}$ (Fig. 7A, see the diamond point). Increasing the L:P during the DH of WPs accelerated the formation of WPM, so that a higher yield of conversion into particles was observed after a much shorter time of DH. However, increasing the lactose content also led to a significant decrease in the WC of the WPM, due to more intense crosslinking of proteins and a lower ability to swell in the aqueous phase. These crosslinking can originate from numerous mechanisms. First, the MR produced a large number of covalent crosslinkers such as dicarbonyl, AGE and melanoidins. However, dicarbonyl, for example, can arise from the degradation of lactose molecules alone, or by the degradation of Amadori compounds formed between protein and lactose. On the other side, exposure of proteins to alkali treatment without any carbohydrates, and even more when coupled with heat treatment such as the one applied in the current study, also causes the racemization of amino acid residues and the formation of dehydroalanine, lysinoalanine and lanthionone crosslinks (Gerrard, 2006).

Two kinds of pathways could be advanced for the formation of whey protein crosslinks. First, the alkaline $\mathrm{pH}$ value could favour the formation of reactive intermediates such as dicarbonyl compounds from lactose alone, that will crosslink the whey proteins. In the Lobry de Bruyn-Alberta van Ekenstein (LA) transformation, glucose can isomerise in enediol anion at alkaline $\mathrm{pH}$ values under a heat treatment (Berg, 1993). According to Van Boekel (1998), besides the Maillard reaction, this contribution can be quantitatively important. Then the enediol anion could undergo either the $\beta$-elimination to form 3-deoxyglucosone or the retro-aldolisation to form glyoxal (Martins \& Van Boekel, 2005a; O'Brien, 1997). These 2 dicarbonyl compounds are highly reactive protein crosslinking molecules (Gerrard et al., 2005). In that hypothesis, the $\mathrm{pH}$ only acted on the degradation of lactose and had no effect on whey proteins. If this mechanism was critical, crosslinks could be formed from any protein material. The second mechanism could arise from the glycation of whey proteins and the formation of Amadori compounds that will further form reactive intermediates that will crosslink proteins. The formation of WPM at alkaline pH values (Famelart et al., 2018) could thus arise from the unfolding of whey proteins and increase in exposure of the lysine residues, besides the fact that high $\mathrm{pH}$ values enhances the formation of dicarbonyl compounds from Amadori compounds, too (Martins \& Van Boekel, 2005b). Further studies are thus needed to elucidate the full mechanism of formation of WPM at alkaline $\mathrm{pH}$ values.

As powders in the current study were produced by freezing and freeze-drying, they probably contained some lactose crystals. We did not evaluate crystalized lactose levels in this study. The extent of lactose crystallization in the powders probably varied with the amount of added lactose. In addition, the levels of crystalized lactose may have evolved during the short storage of powders before DH. Amorphous lactose is more reactive than lactose in its crystalized form, and the mobility of molecules would be greater in the amorphous state than in the crystalized one. As molecule mobility is probably a limiting factor for reactivity in the MR and for protein crosslinking during the DH processes, the levels of crystalized lactose in these powders needs further investigation in future studies.

\section{Conclusions}

Dry heating at $100{ }^{\circ} \mathrm{C}$ of a whey protein freeze-dried powder produced very large WPM. Increasing the lactose content of powders during DH led to an increase in powder browning and $\mathrm{a}_{\mathrm{w}}$, to an increase in the extent of protein denaturation and protein crosslinks and consequently, to an increase in the rate and intensity of the formation of WPM. Whereas the content of WPM increased, their WC decreased. This was probably due to higher levels of protein crosslinking and to a lower tendency for swelling in the aqueous phase. Therefore, $\mathrm{DH}$ for $3 \mathrm{~h}$ with added lactose at $\mathrm{L}: \mathrm{P}=0.42 \mathrm{~g} / 10 \mathrm{~g}$ protein was equivalent in terms of formation of WPM to DH for $36 \mathrm{~h}$ without any lactose addition. However, further studies are required to determine the minimal content of lactose needed to form WPM. These studies will involve analyses of WP powders in which the lactose has been removed. Moreover, understanding the mechanisms of the formation WPM will involve further studies to determine the nature of the links between proteins.

\section{Acknowledgments}

We are grateful to the Regional council of Brittany (grant $\mathrm{N}^{\circ} 13008651$ ) and Regional Council of Pays de la Loire (grant $\mathrm{n}^{\circ} 2014$ 07081) for financial support and INRA for scientific coordination (J. Leonil) through the interregional project PROFIL, managed by the BBA industrial association. The authors would also like to thank M. Pasco for their technical help with HPLC analyses, S. Bugeat for analyses with the $\mathrm{R}$ package and F. Tessier for the determination of the carboxymethyllysine contents of the powders. Language editing services were provided by Dr E. M. Pilling.

\section{Appendix A. Supplementary data}

Supplementary data related to this article can be found at https:// doi.org/10.1016/j.foodhyd.2018.08.018.

\section{References}

Ames, J. M. (1992). The Maillard reaction. Biochemistry of food proteins (pp. 99-154). Dordrecht: Springer-Science B.J.F.Hudson.

Berg, H. E. (1993). Reactions of lactose during heat treatment of milk: A quantitative study. NL: Wageningen Agricultural University.

Cho, R. K., Okitani, A., \& Kato, H. (1984). Chemical properties and polymerizing ability of the lysozyme monomer isolated after storage with glucose. Agricultural \& Biological Chemistry, 48(12), 3081-3089.

Famelart, M.-H., Schong, E., \& Croguennec, T. (2018). Dry heating a freeze-dried whey protein powder: Formation of microparticles at pH 9.5. Journal of Food Engineering, $224,112-120$.

Gerrard, J. A. (2006). Protein cross-linking in food. Food biochemistry and food processing (pp. 223-240). Oxford: Blackwell Publishing.

Gerrard, J. A., Meade, S. J., Miller, A. G., Brown, P. K., Yasir, S. B. M., Sutton, K. H., et al. (2005). Protein cross-linking in food. Annals of the New York Academy of Sciences, 1043(1), 97-103.

Gulzar, M., Bouhallab, S., Jeantet, R., Schuck, P., \& Croguennec, T. (2011). Influence of $\mathrm{pH}$ on the dry heat-induced denaturation/aggregation of whey proteins. Food Chemistry, 129(1), 110-116.

Handa, A., \& Kuroda, N. (1999). Functional improvements in dried egg white through the Maillard reaction. Journal of Agricultural and Food Chemistry, 47(5), 1845-1850.

Hiller, B., \& Lorenzen, P. C. (2010). Functional properties of milk proteins as affected by Maillard reaction induced oligomerisation. Food Research International, 43(4), 1155-1166.

Ibrahim, H. R., Kobayashi, K., \& Kato, A. (1993). Improvement of the surface functionalproperties of $\beta$-lactoglobulin and $\alpha$-lactalbumin by heating in a dry state. Bioscience Biotechnology \& Biochemistry, 57(9), 1549-1552.

Kato, Y., Matsuda, T., Kato, N., \& Nakamura, R. (1988). Maillard reaction of ovalbumin with glucose and lactose. Browning and protein polymerization induced by aminocarbonyl reaction of ovalbumin with glucose and lactose. Journal of Agricultural and Food Chemistry, 36(4), 806-809.

Kneifel, W., \& Seiler, A. (1993). Water-holding properties of milk protein products - A review. Food Structure, 12(3), 297-308.

Liu, Q., Kong, B., Han, J., Sun, C., \& Li, P. (2014). Structure and antioxidant activity of whey protein isolate conjugated with glucose via the Maillard reaction under dryheating conditions. Food Structure, 1(2), 145-154.

Liu, G., \& Zhong, Q. (2013). Thermal aggregation properties of whey protein glycated with various saccharides. Food Hydrocolloids, 32(1), 87-96.

Maillard, L. C. (1912). Action des acides aminés sur les sucres; formation des mélanoïdines par voie méthodique. Comptes Rendus Des Séances de l'académie Des Sciences, janvierjuin (154).

Manzocco, L., Calligaris, S., Mastrocola, D., Nicoli, M. C., \& Lerici, C. R. (2000). Review of 
non-enzymatic browning and antioxidant capacity in processed foods. Trends in Food Science \& Technology, 11(9), 340-346.

Manzocco, L., \& Maltini, E. (1999). Physical changes induced by the Maillard reaction in a glucose-glycine solution. Food Research International, 32(4), 299-304.

Martinez-Alvarenga, M. S., Martinez-Rodriguez, E. Y., Garcia-Amezquita, L. E., Olivas, G. I., Zamudio-Flores, P. B., Acosta-Muniz, C. H., et al. (2014). Effect of Maillard reaction conditions on the degree of glycation and functional properties of whey protein isolate - maltodextrin conjugates. Food Hydrocolloids, 38, 110-118.

Martins, S. I. F., Jongen, W. M., \& van Boekel, M. A. J. (2000). A review of Maillard reaction in food and implications to kinetic modelling. Trends in Food Science \& Technology, 11(9-10), 364-373.

Martins, S. I. F. S., \& Van Boekel, M. A. J. S. (2005a). A kinetic model for the glucose/ glycine Maillard reaction pathways. Food Chemistry, 90(1), 257-269.

Martins, S. I. F. S., \& Van Boekel, M. A. J. S. (2005b). Kinetics of the glucose/glycine Maillard reaction pathways: Influences of $\mathrm{pH}$ and reactant initial concentrations. Food Chemistry, 92(3), 437-448.

Maskan, M. (2001). Kinetics of colour change of kiwifruits during hot air and microwave drying. Journal of Food Engineering, 48(2), 169-175.

Monahan, F. J., German, J. B., \& Kinsella, J. E. (1995). Effect of pH and temperature on protein unfolding and thiol/disulfide interchange reactions during heat-induced gelation of whey proteins. Journal of Agricultural and Food Chemistry, 43(1), 46-52.

Mottram, D. S. (2007). The Maillard reaction: Source of flavour in thermally processed foods. In R. G. Berger (Ed.). Flavours and fragrances. Chemistry, bioprocessing and sustainability (pp. 269-283). Berlin, Heidelberg: Springer.

Mulcahy, E. M., Park, C. W., Drake, M., Mulvihill, D. M., \& O'Mahony, J. A. (2018). Enhancement of the functional properties of whey protein by conjugation with maltodextrin under dry-heating conditions. International Journal of Dairy Technology, 71(1), 216-225

Nicolai, T., Britten, M., \& Schmitt, C. (2011). $\beta$-Lactoglobulin and WPI aggregates: Formation, structure and applications. Food Hydrocolloids, 25(8), 1945-1962.

Niquet-Léridon, C., \& Tessier, F. J. (2011). Quantification of Ne-carboxymethyl-lysine in selected chocolate-flavoured drink mixes using high-performance liquid chromatography-linear ion trap tandem mass spectrometry. Food Chemistry, 126(2), 655-663.

Norwood, E.-A., Chevallier, M., Le Floch-Fouéré, C., Schuck, P., Jeantet, R., \& Croguennec, T. (2016). Heat-induced aggregation properties of whey proteins as affected by storage conditions of whey protein isolate powders. Food and Bioprocess Technology, 9(6), 993-1001.

O'Brien, J. (1997). Reaction chemistry of lactose: Non-enzymatic degradation pathways and their significance in dairy products. In P. F. Fox (Ed.). Advanced dairy chemistry volume 3 - Lactose, water, salts and vitamins (pp. 155-231). Boston, MA: Springer.

Partanen, R., Torkkeli, M., Hellman, M., Permi, P., Serimaa, R., Buchert, J., et al. (2011) Loosening of globular structure under alkaline $\mathrm{pH}$ affects accessibility of $\beta$-lactoglobulin to tyrosinase-induced oxidation and subsequent cross-linking. Enzyme and Microbial Technology, 49(2), 131-138.

Schmitt, C., Bovay, C., \& Frossard, P. (2005). Kinetics of formation and functional properties of conjugates prepared by dry-state incubation of $\beta$-lactoglobulin/Acacia gum electrostatic complexes. Journal of Agricultural and Food Chemistry, 53(23), 9089-9099.

Schong, E., \& Famelart, M.-H. (2017). Dry heating of whey proteins. Food Research International, 100(Pt 2), 31-44.

Schong, E., \& Famelart, M.-H. (2018). Dry heating of whey proteins leads to formation of microspheres with useful properties. Food Research International, 113, 210-220.

Soboleva, A., Schmidt, R., Vikhnina, M., Grishina, T., \& Frolov, A. (2017). Maillard proteomics: Opening new pages. International Journal of Molecular Sciences, 18(12), 2677.

Taulier, N., \& Chalikian, T. V. (2001). Characterization of pH-induced transitions of $\beta$ lactoglobulin: Ultrasonic, densimetric, and spectroscopic studies. Journal of Molecular Biology, 314(4), 873-889.

Van Boekel, M. A. J. S. (1998). Effect of heating on Maillard reactions in milk. Food Chemistry, 62(4), 403-414.

Wang, Q., He, L., Labuza, T. P., \& Ismail, B. (2013). Structural characterisation of partially glycosylated whey protein as influenced by $\mathrm{pH}$ and heat using surface-enhanced Raman spectroscopy. Food Chemistry, 139(1-4), 313-319. 